perly cared for, they consider themselves superior to natives, while the whites are not inclined to make a difference between them and Negroes, so when they do not find contact with the native society, their situation may become hopeless, and it is no wonder that many of them get no firm foothold in life. On the other hand, it cannot be overlooked that many West Africans with an admixture of white blood have become leading personalities in public life and have distinguished themselves in many ways. The position of the African half-breed is well characterized in the following dictum of M. Augagneur, Governor General of Madagascar: ' With his qualities, the half-breed will be somebody in the native world, but he will never be more than a déraciné, a déclassé, in a European population.'

\title{
Native Peasant Production
}

THE report just issued by Professor C. Y. Shephard after his investigation of Gold Coast cocoa production (Report on the Economics of Peasant Agriculture in the Gold Coast) contains interesting, if depressing, information. The phenomenal prosperity that cocoa has brought to the Gold Coast has been taken to show that economic as well as social reasons justify the encouragement of production by the small native holding rather than the plantation. Professor Shephard does not dissent from this conclusion; but he points out that the great productivity of the Gold Coast cocoa is not due to natural advantages of soil and climate which would justify a belief in its indefinite continuance, but is a characteristic of all cocoa cultivation in its early stages. The point must soon be reached where the yield of existing plantations will rapidly decline, and measures are needed to compensate for this by improving the quality and raising the present low standard of efficiency in cultivation. Professor Shephard recommends a scientific investigation into soil possibilities and appropriate methods of growing, with more careful inspection and grading, which should aim at progressively raising the standards required.

The adoption of more efficient methods necessitates first and foremost the interest of the farmer himself; it may also involve financial outlay, and sometimes-for example, in the fermenting process-the economy of largescale operations is important. For all these ends Professor Shephard advocates the development of the co-operative societies which have already become popular in the Gold Coast during the last five years.

His analysis of the financial side of cocoa production is particularly interesting to the sociologist. Despite the fact that the farmer still grows his own food, the goods which he normally expects to purchase have now reached a proportion where he can be said to have adopted a money economy. Yet all his income is received during the few months of the marketing season. Rather than calculate his expenditure so as to make it last through the year, 
he spends it and then borrows from the money-lender. Funeral and marriage ceremonies, growing in magnificence as the general standard rises, account for much indebtedness; litigation is the other most important cause. The crop is sometimes mortgaged to the creditor, who takes possession and keeps it till the debt is paid; and in this way alien natives are acquiring rights which ' may have important reactions on political organization'.

The reduction in incomes 'from a comfortable competency to a mere pittance', that has begun already with the fall in the price of cocoa, has led to further borrowing in an attempt to maintain the existing standard of living. Such debtors cannot hope to repay except by an increase in industry and efficiency which has not been made. The money-lenders have lost heavily, and the rate of interest has naturally risen higher and higher. Here there is a particularly important field for co-operation in the organization of credit for productive purposes on reasonable lines; but some supervision will be necessary. Another activity which co-operative societies must undertake is fermenting, which cannot be done efficiently with small quantities of cocoa. A central marketing association is also called for.

It is interesting to compare with these conclusions those drawn by Professor Macmillan in his Warning from the West Indies. ${ }^{\mathrm{I}} \mathrm{He}$, too, believes that the peasant farmer operates on too small a scale to hold his own in modern conditions, where 'agriculture has become a science and marketing an art'. In particular he cannot be made the basis of the economic development necessary to raise the revenues required for essential social services. The West Indies differ from West Africa in that peasant and large planters exist side by side; and here Professor Macmillan suggests that efficient development could be based on co-operation between the two--a suggestion that may have its relevance for other parts of Africa. He regards as particularly hopeful the 'cane-farming' system, whereby tenants on large estates agree to grow a fixed quantity of cane for selling to the estate or to some factory. The estate often directs the work and may finance the grower, and the standard of efficiency attained with this assistance is higher, as might be expected, than that of the peasant left to his own devices.

Professor Macmillan's study covers a much wider field than Professor Shephard's-the present state of development of the West Indies as a whole and its relation to the degree of efficiency in economic organization-and the type of policy which he advocates is therefore necessarily also more comprehensive and less detailed. His book provokes comparisons not only with West Africa, where one would naturally look first for parallels, but in other aspects with many other African territories, and with nearly all the aspects of African policy which are matters of doubt and controversy. (Communicated by DR. L. P. MAIR.)

I W. M. Macmillan. Warning from the West Indies, a Tract for Africa and the Empire. London: Faber and Faber. Pp. 213. 1936. 8s. 6 d. 